\title{
Mapping the Hydrologic Response of the Brazilian hydrologic regions and their variability associated with El Niño and La Niña \\ (doi:10.4136/ambi-agua.3)
}

\author{
João Vianei Soares; Felix Carriello; Nelson Jesus Ferreira; Camilo Daleles Rennó \\ Instituto Nacional de Pesquisas Espaciais \\ E-mail: vianei@dsr.inpe.br, \{felix, camilo\}@dpi.inpe.br, nelson@cptec.inpe.br
}

\begin{abstract}
Brazil has a wide-ranging network of rivers flowing northeast, east, north or southward. The water running off these basins may vary a great deal with climate and spatial distribution of rainfall rates. This paper analyzes the Hydrological Response (HR) of the eight major Brazilian river basins and sub-basins for a period matching 30 years of data, from 1970 to 2000. HR refers to river flow normalized by rainfall over the basin. The atmospheric forcing strongly modulates the HR at synoptic scales. At local scales, geology and land use also play an important role. The average spatial HR reached values as high as 0.7 in the west of Brazilian Amazon. We estimated "average" to "high" values in central and western Amazon (0.3-0.5) and "average" in the center-south and southeast (around 0.3). We found HR in the northeast semi-arid of Brazil classified as "very low" (close to 0.1). Brazil has climates changing from humid and rainy to semi-arid regions. Besides analyzing the regional distribution of the HR across the country, we explored the effects of the interanual variability associated with ENSO and La Niña. We used the normal climate average over thirty years as the standard for comparing the differences associated with the two anomalies. We noticed that the subbasins of the southern regions showed positive variations in water production while the Brazilian Amazon basin showed no response. Also, the areas of lower HR in the northeast Brazil were further reduced.
\end{abstract}

Keywords: Hydrologic mapping; interannual anomalies.

\section{Resposta hidrológica das regiões brasileiras e sua variabilidade associada com El Nino e La Nina}

\section{RESUMO}

O Brasil possui uma vasta densidade de rios importantes drenando para leste, oeste, sul e norte. A vazão destas bacias varia com o clima e a distribuição espacial de taxas de precipitação. Analisamos aqui a resposta hidrológica das oito grandes bacias hidrológicas do Brasil e suas sub-bacias, para um período de 30 anos de dados, de 1970 a 2000. Resposta hidrológica é definida como a vazão de uma bacia normalizada pela precipitação espacializada sobre sua superfície. A forçante atmosférica modula a resposta das grandes bacias. Na escala local, o controle geológico também é importante. A resposta hidrológica média atinge 0.7 (classificada como elevada) para a região oeste da Amazônia. Valores de médios a elevados (0.3-0.5) foram mapeados na parte central e sudoeste da Amazônia enquanto valores médios (0.3) prevalecem nas regiões sudeste e sul. No semi-árido do nordeste, a resposta é muito baixa (0.1). O Brasil possui climas que vão do quente e chuvoso ao semi-árido. Além de analisar a variabilidade regional da resposta hidrológica, avaliamos também os efeitos da variabilidade inter-anual associada aos eventos ENSO e La Niña. 
Usamos a resposta média de 30 anos como referência. Notamos que as bacias do sul do país mostraram variação positiva, as da Amazônia se mantiveram neutras e as do nordeste mostraram resposta hidrológica ainda mais reduzida.

Palavras-chave: Hidrologia; Resposta hidrológica; El Niño; La Niña

\section{INTRODUCTION}

Hydrological Response is the speed of reaction of storm flow following rainstorms in the drainage channels (Hewllet; Hibbert, 1967; Hewlett, 1982). This response can vary within the basin itself depending on its scale. Despite the original definition, as it normalizes water production to rainfall rates, its average value over many years is interpreted as the average water balance, since water storage variation in the soil is negligible over several hydrologic years. In this way, Hydrologic Response maps of basins could be a valuable analysis tool for water production assessment. Surface water flowing in rivers is the greatest source of freshwater for human use, for domestic and industrial use, for agriculture, and for the generation of energy. Water from rainfall follows different paths, with part feeding the aquifers, remaining in storage for a certain time before reaching rivers and channels and part evaporating from the soil surface or from tree canopies. Stored water also reaches plants roots and then the atmosphere by transpiration. Thus, a basin's average Hydrologic Response, given a significant interval to allow water redistribution in the soil, matches the balance of water produced within a basin integrated in time (Carriello, 2004). For large hydrological basins, climate forcing is determinant of the Hydrologic Response. Geology, the physical properties of soils that define water storage capacity (depth and texture) influence the residence time for the water in the basin. The soil cover (type and density of vegetation) that affects the water infiltration rates into the soil is also important to the Hydrologic Response (Hewlett, 1982).

This work was carried out to discuss and make available Hydrologic Response maps for the large hydrological regions of Brazil.

\section{DATA, TOOLS AND METHODS}

As previously stated in this work we compile, discuss and make available Hydrologic Response maps for the large hydrological regions of the country, as defined by ANA, the Brazilian National Water Agency. The eight hydrologic zones are the Amazon, AraguaiaTocantins, the North-Northeast Atlantic, São Francisco, the Eastern-Atlantic, ParaguayParaná, Uruguay and the Southeast Atlantic. Also, we have assessed how interannual hydrometeorological variability can regionally influence the Hydrologic Response, considering the "El Niño" and "La Niña" in two strong events within the 30-year period studied from 1970 to 2000. Figure 1 shows the regions.

\subsection{Hydrological Response: the concept}

As above Hydrological Response, $H R$, refers to how rainstorms evolve into storm flow in the drainage channels. Hydrological response is the ratio between river flow and rainfall. In other words, it is the water production of a given hydrographic basin normalized by the rainfall rates that takes place in it. Then:

$$
H R=\frac{Q}{P}
$$




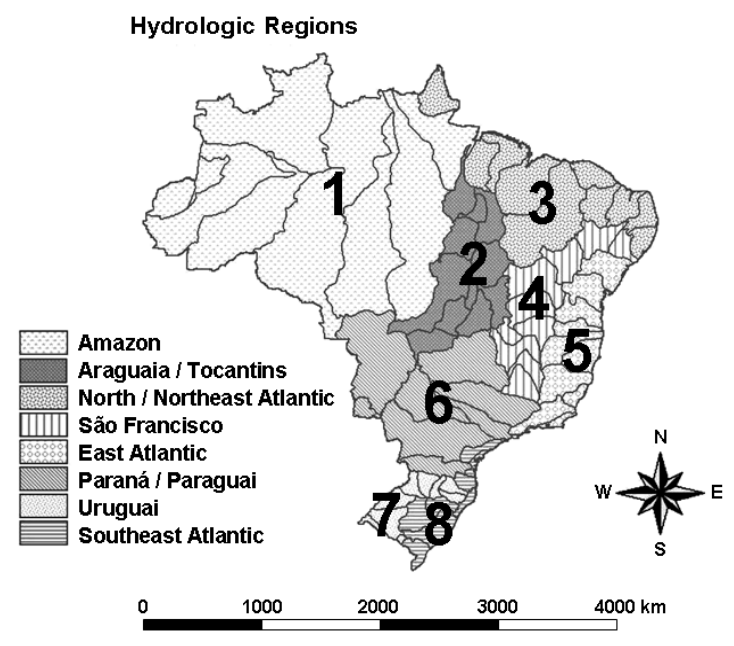

Figure 1. Hydrologic regions and subbasins of Brazil: 1) Amazon; 2) Araguaia / Tocantins; 3)North / Northeast Atlantic; 4 São Francisco; 5) East Atlantic; 6) Paraná / Paraguay; 7) Uruguay and 8) Southeast Atlantic.

Source: Adapted from ANA, Agência Nacional de Águas - Brasil (2003).

$\mathrm{Q}$ is the river flow in a stretch of water normalized by the area of the basin contributing water to a particular river section. $\mathrm{P}$ is rainfall determined by the weighted average considered for the basin. The interpolation considers the gauging station distribution and a representative surface area, a classic method known as Thiessen polygons. In the original definition, Hydrologic Response refers to individual rainfall events over $25 \mathrm{~mm}$, as it is unlikely that lower rainfall would produce runoff and change the river flow regime. However, it is more usual to estimate the average Hydrologic Response by integrating in time rainfall and river flow for the same fluviometric station. Mathematically:

$$
H R=\left\langle\frac{Q}{P}\right\rangle
$$

$\mathrm{Q}$ (is calculated from the ratio between river flow (in $\mathrm{L}^{3} \mathrm{~T}^{-1}$ units) and the area $\left(\mathrm{L}^{2}\right)$ drained For some basins of high order rivers, such as the São Francisco River, we count the increase in $\mathrm{Q}$ between two consecutive fluviometric stations for the same basin or subbasin. Time is the implicit integration variable. With rainfall ( $\mathrm{P}$, also in $\mathrm{L}$ units) it follows that Hydrologic Response is dimensionless. Then one can interpret $H R$ as the fraction of the integrated rain rates which result in water production in a given basin. This becomes a relevant piece of information for water use management and planning purposes for the regions of interest. The use of river flow rates data alone does not give comparable measures across the regions.

\subsection{River flow data}

To draw the Hydrologic Response maps, we gathered 74 out of the 76 subbasins in Brazil of the eight large hydrological regions of the country. We selected the stations with river flow data from surveys from the "Fluviometric Station Inventory" (Brasil, 1997), and from the "Agência Nacional de Águas" (Brasil, 2003). From these sources we picked the stations which had the data for the period from 1970 to 2000, as well as information available on the area drained by the station, geographical coordinates (latitude, longitude), and its 
working period. The data, consisting of river flow from each fluviometric station available at the ANA website (http://www.ana.gov.br), was initially restored in daily averages and converted into monthly and annual averages to calculate the annual runoff for each surveyed basin.

\subsection{Rainfall data}

The rainfall data used to calculate the HR were compiled and interpolated by the Tyndall Center for Climate Change Research (New et al., 1999, 2000, 2002). The data are available in grids of $0.5^{\circ} \times 0.5^{\circ}$ for the whole terrestrial globe for the period from 1900 to 2000. These data are in monthly archives and were processed from data handed over by meteorological agencies and research institutions from several countries. Among providers of data are the International Center for Tropical Agriculture (CIAT), the Climatic Research Unit (CRU Tyndall Center) and the World Meteorological Organization (WMO). We integrated the monthly rainfall data into annual data to calculate the Hydrologic Response.

We used spatial interpolation of the rainfall data to estimate the values for places where there is no data available. The interpolator chosen was the "Thin-plate spline," which considers polynomial operators and uses point data to adjust a surface, given a set of points. This technique is suitable for areas in which point data has irregular spatial distribution, as is the case for Brazil. The surface created by this interpolator presents an adjustment to reduce sharp changes in the generation of the isoline data under interpolation. The resulting surface of rainfall is associated with latitude, longitude and elevation (New et al., 1999).

\subsection{Estimating the Hydrologic Response}

The river flow and rainfall data for the time frame between 1970 and 2000 were used in calculating the annual Hydrologic Response from 74 subbasins of the eight hydrological regions in Brazil. The eight regions comprise the whole country (Amazon, AraguaiaTocantins, Atlantic N-NE, São Francisco, eastern Atlantic, Paraguay-Paraná, Uruguay and the southeast Atlantic). The National Water Agency has organized its data banks into 12 regions. For this work the basins from the Atlantic North-Northeast include the basins from Parnaíba River and the northeast Atlantic, as the southeastern and eastern Atlantic basins are integrated as one single region. To present the results we used the shareware GrADS (Grid Analysis and Display System), dedicated to manipulate and allow visual analysis of scientific data with spatial representation (available at http://grads.iges.org/grads/grads.html). These results were interpolated, having considered the radius of influence from the measuring stations and plotted by the application in annual graphs for the period under consideration. In a simplified form, the closer the station, the greater the weight exercised in considering the estimated value of the data. For this study a lag of two months was set up between the rainfall and river flow. We fixed this lag after the analysis of rainfall and river flow for several subbasins representing all hydrological regions, showing that peak river flow happens, on average, two months after the greatest rainfall events (in monthly averages). Thus, for a given month, calculating the Hydrologic Response should be done considering the rain from two months before. For example, for the rain from October 1970, the river flow is from December 1970.

In this way we calculated the Hydrologic Responses for 74 subbasins out of the 76 subbasins in Brazil. The two subbasins not considered (80 and 89) did not have enough river flow data in fluviometric stations for the period studied.

In processing the rainfall data within the GrADS environment, we used a method by which the data from a certain surface (sub-basin) could be calculated just for this specific area (masks). From here the annual average of spatially spread values could be determined, in millimeters, for each one of these subbasins for each year in the period under consideration. 
The rainfall data for Brazil are available for the region between $6^{\circ} \mathrm{N}$ to $34^{\circ} \mathrm{S}$ and $74^{\circ} \mathrm{W}$ to $34^{\circ} \mathrm{W}$. (New et al., 1999, 2000, 2002). Given the working scale, topography is not taken into account.

\subsection{Brazilian hydrographic regions}

As shown in Figure 1, Brazil has been divided into eight hydrographic regions. According to the drainage pattern, there are two main types of basin. The first category is formed by basins which drain to a single river, the subbasins being linked one after the other. In this first category are basins: 1 (Amazon hydrographic region), 2 (Araguaia-Tocantins hydrographic region), 4 (São Francisco hydrographic region), 6 (Paraná-Paraguay hydrographic region) and 7 (Uruguay hydrographic region). The second category are hydrographic regions whose basins' rivers flow to the Atlantic Ocean, not having a main river (with some exceptions, for example the subbasin Paraíba do Sul) but several rivers flowing to the Atlantic. This second group includes basins in regions 3, 5 and 8 (Atlantic NorthNortheast hydrographic region, Southeast area and East area, respectively). The large basins are divided into smaller basins formed by the main tributaries. Most of the large hydrographic regions are subdivided into ten subbasins. In Brazilian territory alone, the Paraná-Paraguay (6) hydrographic region has eight subbasins and the Uruguay (7) and East Atlantic region (8) has nine. The total number of subbasins analyzed was 76.

\subsection{Hydrological response maps analyzes}

To produce Hydrologic Response maps of the Brazilian subbasins we considered the hydrological year beginning on $1^{\text {st }}$ October and ending on $30^{\text {th }}$ September of the following year. October is the beginning of the rainy season for the most of the country, except for a few subbasins north of the equator in the Amazon region. River flow data was gathered for the period from 1970 to 2000 from fluviometric stations installed on the rivers of the respective subbasins.

The use of the whole period of data made possible what can be called a map of the Hydrologic Response norms in Brazil. Two El Niño and La Niña hydrological years were also analyzed (interannual and spatial hydrometeorological precipitation variability), as case studies for the effect of interannual variability on Hydrologic Response.

Interannual variability is, in the case of rain, more obvious when atmospheric circulations influence large areas and the precipitation increases or reduces in different regions, bringing about a consequent increase or decrease of the Hydrologic Response. One example is the ENSO (El Niño Southern Oscillation), a disturbance in the tropical Pacific ocean-atmosphere with consequences for the weather and the climate around the globe (Trenberth, 1997). In the years with a persistent and strong ENSO signal, it exercises a distinct meteorological influence for the southern and northeastern regions of Brazil. For the former it causes an increase in the average precipitation, whilst for the latter, a decrease from the average values for the semi-arid climate, including severe droughts in certain years (Marengo; Uvo, 1996) On the other hand, La Niña (cooling the equatorial waters of the Pacific Ocean) produces above average rainfall in the northeast semi-arid region and below average for the southern (Marengo; Uvo, 1996). Figure 2 pictures the typical anomalies for the surface temperature of the equatorial Pacific Ocean resultant from El Niño (warming) and La Niña (cooling) oscillations.

The 1982-83 El Niño can be considered one of the strongest in the $20^{\text {th }}$ Century (Marengo et al., 1998b) and whose influence on the Hydrologic Response is assessed here. This El Niño was neither forecast nor recognized by the scientific community in its early phases. The effects of the La Niña discussed here are from the analysis of the spatial variation 
of Hydrologic Response for the period 1974-75, also a well-established and representative event. We did not include these two years when estimating the average for the period between 1970 and 2000. We carried out paired Student's t-test statistics to analyze the differences in Hydrologic Response of subbasins in the same hydrographic region associated with the two strong anomalies.

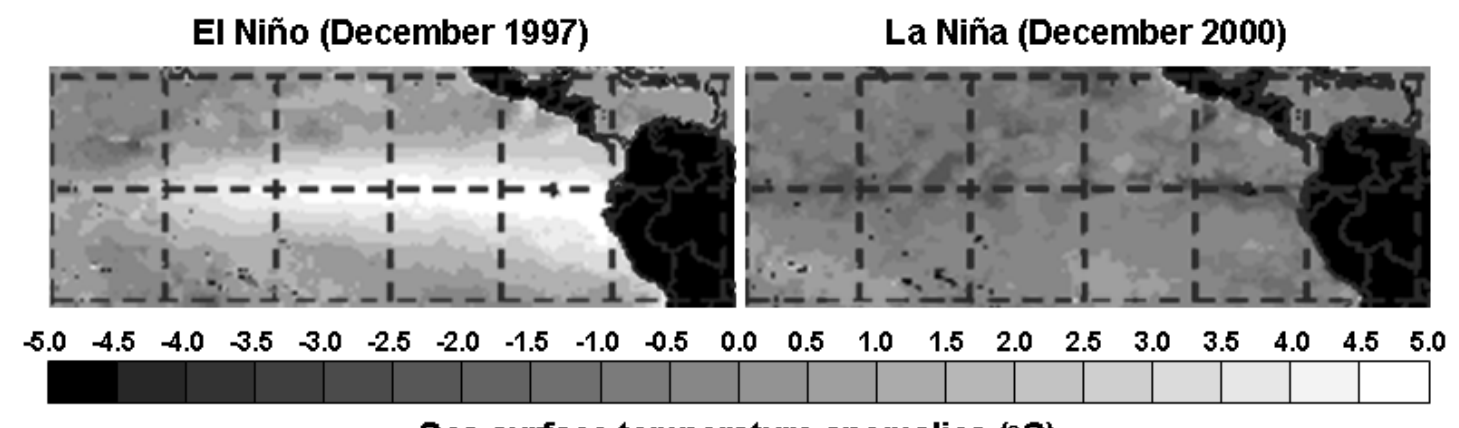

Sea surface temperature anomalies $\left({ }^{\circ} \mathrm{C}\right)$

Figure 2. ENSO and La Niña anomalies in sea surface temperature of the Equatorial Pacific Ocean. SOURCE: Adapted from http://www.elnino.noaa.gov/lanina.html.

\section{RESULTS AND DISCUSSION}

On the global annual hydrological balance for the continents, from a total precipitation of $0.1 \mathrm{~km}^{3}$, a fraction of $0.07 \mathrm{~km}^{3}$ returns to the atmosphere by evapotranspiration, and $0.03 \mathrm{~km}^{3}$ flows into the oceans (Hewlett, 1982). It is therefore inferred that average global Hydrologic Response is 0.3 (that is, $30 \%$ of rainfall is transformed into rivers). We can then propose a table of classes of Hydrologic Response (Table 1).

Table 1. Table of range and associated classes of Hydrologic Response considering the global average.

\begin{tabular}{c|c}
\hline Range & Class \\
\hline$<0.15$ & Very low \\
$0.15-0.25$ & Low \\
$0.25-0.35$ & Average \\
$0.35-0.45$ & High \\
$>0.45$ & Very high \\
\hline
\end{tabular}

Figure 3 presents the Hydrologic Response from the annual averages for the 30 -year period (1970-2000). The average spatial HR standard presents very high values (reaching 0.7, i.e. $70 \%$ of rainstorms become river flow out of the drainage area) in the west of the Brazilian Amazon region and in some subbasins of southern Brazil. We estimated average to high values in central and western Amazonia (0.3-0.5) and average values in the center south and southeast (around 0.3). We found a very low HR in the northeast semi-arid of Brazil and the center west region at the border of Brazil with Bolivia (close to 0.1).

Hydrological response cannot be explained just as a direct and linear product of precipitation. As already stated, other factors, such as the soil coverage, basin morphology, soil types and geology which make up the geospatial structure, also influence this variable (Woodruf; Hewlett, 1970). This holds true especially for microbasin and individual rainstorm events. When a time period is considered for characterizing the climate norms (30 years in this case), energy (incoming solar radiation) also plays an important role along with soil cover. Tropical 
rain forests have leaf area indices above 5.0 (Roberts et al., 1996). Hence, available soil water storage combined with solar radiation which varies little throughout the year (at latitudes below $10^{\circ}$ ), leads to rates of evapotranspiration which reach almost $1,500 \mathrm{~mm}$. Similar rates were found by Roberts et al (1996), Soares and Almeida (2001), Almeida and Soares (2003) for the rain forests and Eucalypt plantations. With precipitation rates of 2,200 to 2,500 mm, the Hydrologic Responses are not so much above the worldwide average (30\% of worldwide continental precipitation flowing into the oceans) (Hewlet, 1982). But, still 700 to $1000 \mathrm{~mm}$ of evapotranspiration may mean a lot for regional export of water vapor and the amount recycled in the region itself. For the westernmost part of the Brazilian Amazon where annual precipitation exceeds 3,000 mm, Hydrologic Response reaches very high values. This may be explained by less evapotranspiration because of an increase in cloud cover and a consequent reduction in available incoming solar radiation.

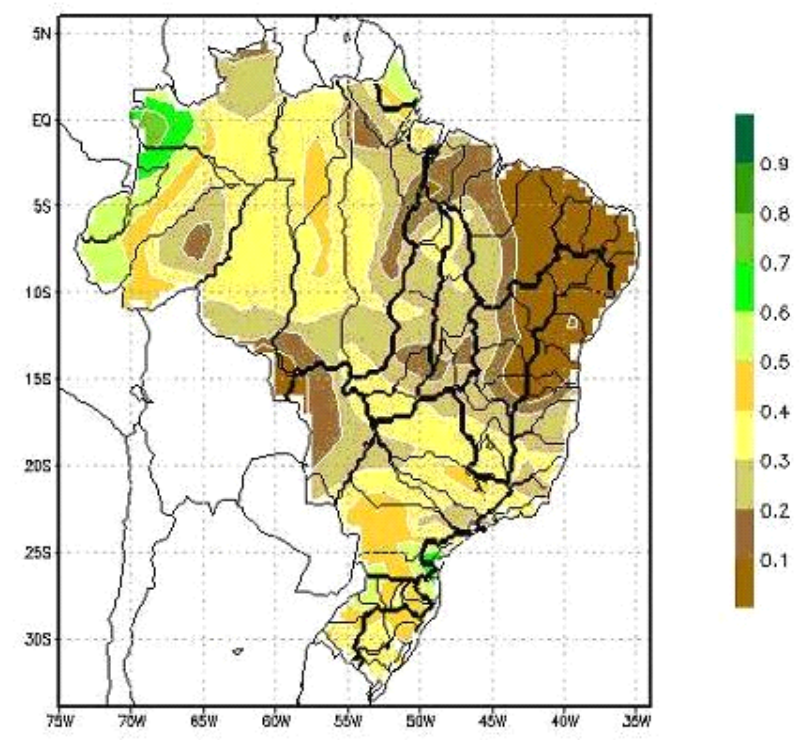

Figure 3. Average Hydrologic Response for the period 1970 to 2000 .

The Brazilian northeast is characterized, in its interior (the "sertão" covered by the "Caatinga", a savanna-like vegetation), by a semi-arid climate which has led to creating a geopolitical region denominated "Polígono das Secas", which translates as "Drought Area". In this huge area droughts reach over 1,500 municipalities. Local administrations constantly search for solutions on several levels such as building dams for water storage and desalination of groundwater. More recently, the Federal Government decided on diverting part of the flow from the São Francisco River to supply several of the region's rivers. The annual average rainfall is around $800 \mathrm{~mm}$ or lower. A large part of the northeast (taking in the basins from North-Northeast Atlantic and part of São Francisco), is characterized by very low Hydrologic Responses (below 0.15 , average close to 0.10 ). This means that only about $10 \%$ of the total annual rainfall drains out as river waters in a given regional drainage subbasin. These responses are explained by combining two variables in the hydrological balance: lower than average rainfall and a high amount of solar energy. Figure 4 shows that in the semi-arid sertão the maximum irradiation has average annual values of $6000 \mathrm{Whm}^{-2}$, values $30 \%$ greater than those for the east of the southern region of the country (Brasil, 1998). Again, although a map of HR is not a new information, it is a valuable way of presenting and interpreting data for the planning and decision making on water, which is of particular interest for areas often subject to low rainfall. 
Following the Hydrologic Response patterns during the period studied, it is seen that some regions present patterns that repeat themselves, it being possible to define this behavior. The northern region presents high average responses, the northeast region low responses, the center south and southeast regions have average responses; and the southern region presents average to high responses. However, this pattern is associated with the vegetation distribution through the large hydrological regions of the country and may be analyzed within this geographical context.

The spatial distribution of the Hydrologic Response presents significant variations in certain years. One of the causes of the interannual hydrometeorological variability is the presence of the El Niño and La Niña. Marengo and Uvo (1996) stress the correspondence between rain and river discharge is not linear; however, it can be assumed that rainfall anomalies provoke discharge changes of the same dimensions. According to them, the discharges are part of the spatial variability of precipitation within the basin. In this way, these precipitation anomalies can be related to Hydrologic Response.

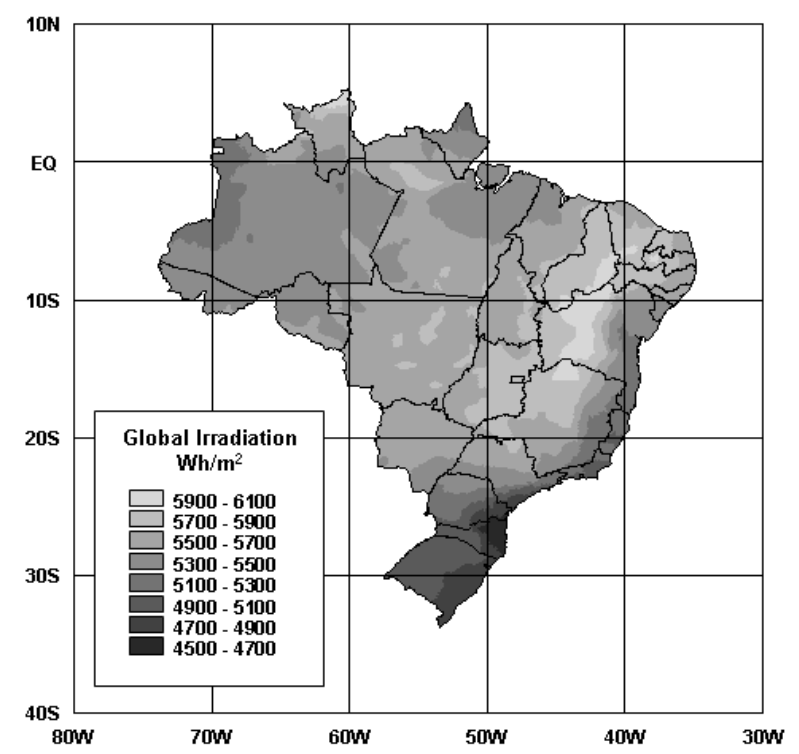

Figure 4. Annual Average Irradiation $\left(\mathrm{Wh} / \mathrm{m}^{2}\right)$ for the period 1995-98.

Source: Adapted from the Atlas of Solar Irradiation in Brazil - INMET (Brasil, 1998).

Figure 5 shows the response map for the El Niño 1982-83. In the northeast region, for example, the already low HR levels (between the parallels $35^{\circ}-45^{\circ} \mathrm{W}$; and $2.5^{\circ}-15^{\circ} \mathrm{S}$ ) become even lower. The center-southern and southern regions basins produce more water because ENSO leads to increased precipitation in these areas.

To show another variablility in the other sense, figure 6 shows the Hydrologic Response map based on data for the year 1974-1975, with La Niña. An increase can be seen in the response in the northeast region, above all between the $45^{\circ} \mathrm{W}$ and $38^{\circ} \mathrm{W}$ in comparison to the 30-year annual average. Conversely, there is also a decline in Hydrologic Response in some subbasins of the southern hydrological region. Visual identification alone is difficult because of the gray scale chosen to represent the overall classes of Hydrologic Response. 


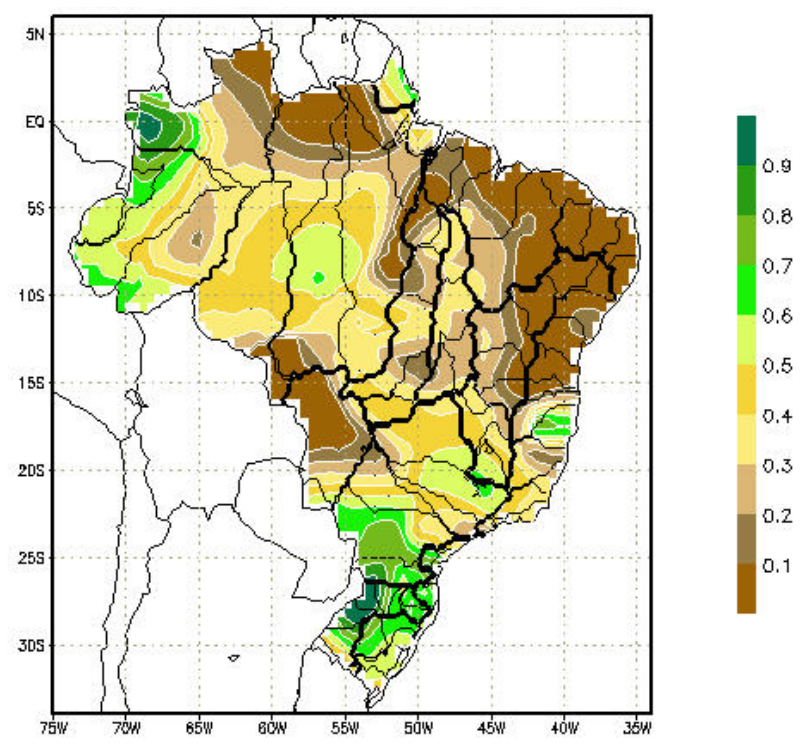

Figure 5. Hydrologic response for the ENSO 1982-83 event. The semi-arid northeast experience negative water production while center-south and south basins display positive responses.

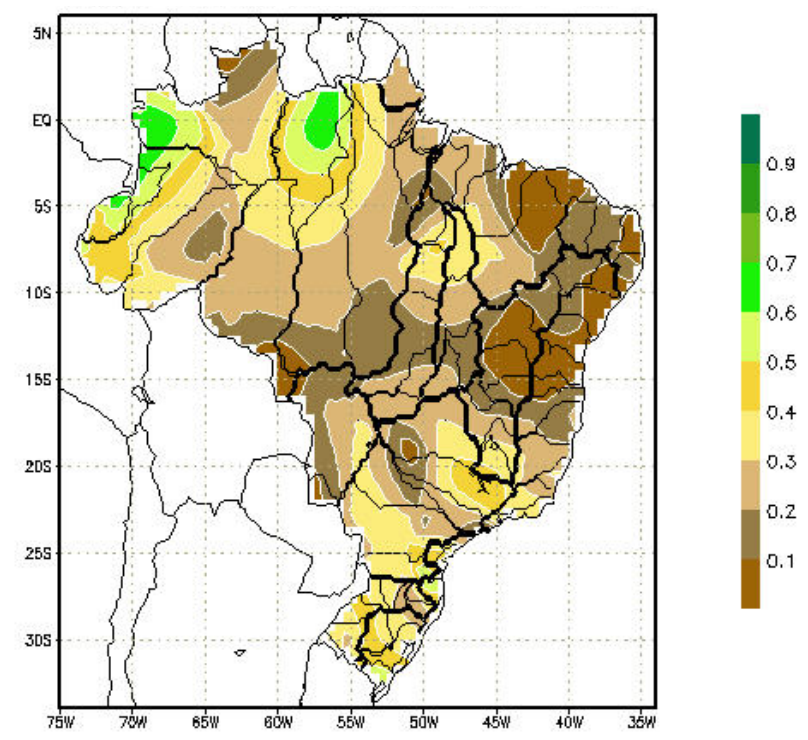

Figure 6. Annual average Hydrologic Response (HR) 1974-1975.

We used statistical analysis to compare the relative behavior of Hydrologic Responses for years of strong El Niño or La Niña. The assumption was that events with strengths close to the ones studied would induce similar results whenever they happen again. The numbers of the northeast region (number ID 32-39, 47, 49) are shown in Table 2. For the particular El Niño 1982/83 event, the averaged regional Hydrologic Response associated with negative precipitation anomalies reduced from 0.08 (or $8 \%$ ) to 0.05 (or 5\%). Conversely for the 1974/75 La Niña the average rose from 0.10 to 0.12 (12\%). Paired Student's t-test performed to compare these two Hydrologic Responses showed that they are significantly different at $1 \%$ (p-value 0.0002 ). The positive average of La Niña - El Niño of 0.07, shown in Table 2, is 
SOARES, J. V.; CARRIELLO, F.; FERREIRA, N. J; RENNÓ, C. D. Mapping the hydrologic response of the Brazilian hydrologic regions and their variability associated with El Niño and La Niña. Ambi-Agua, Taubaté, v. 1, n. 1, p. 21-36, 2006. (doi:10.4136/ambi-agua.3)

a clear sign of moister conditions during the particular event (with more water production for the river basins).

Table 2. Comparison of the changes is Hydrologic Region of subbasins located in the semiarid northeast region, for two strong events of El Niño (1982/82) and La Niña (1974/75). The left most column is the basin ID number and the last line are the mean values.

\begin{tabular}{|c|c|c|c|c|c|c|}
\hline $\begin{array}{l}\text { Basin } \\
\text { ID }\end{array}$ & $\begin{array}{l}\text { 30-year } \\
\text { Average }\end{array}$ & $\begin{array}{c}E l \\
\text { Niño }\end{array}$ & $\begin{array}{c}\text { La } \\
\text { Niña }\end{array}$ & $\begin{array}{c}\Delta \\
\text { El Niño }\end{array}$ & $\begin{array}{c}\Delta \\
\text { La Niña }\end{array}$ & $\begin{array}{c}\Delta \\
(\text { La Niña - El Niño) }\end{array}$ \\
\hline 32 & 0.17 & 0.09 & 0.22 & -0.08 & 0.05 & 0.13 \\
\hline 33 & 0.15 & 0.13 & 0.17 & -0.02 & 0.02 & 0.04 \\
\hline 34 & 0.11 & 0.12 & 0.15 & 0.01 & 0.04 & 0.03 \\
\hline 35 & 0.02 & 0.01 & 0.04 & -0.01 & 0.02 & 0.03 \\
\hline 36 & 0.07 & 0.04 & 0.14 & -0.03 & 0.07 & 0.10 \\
\hline 37 & 0.08 & 0.04 & 0.13 & -0.04 & 0.05 & 0.09 \\
\hline 38 & 0.04 & 0.02 & 0.07 & -0.02 & 0.03 & 0.05 \\
\hline 39 & 0.06 & 0.05 & 0.09 & -0.01 & 0.03 & 0.04 \\
\hline 47 & 0.04 & 0.01 & 0.13 & -0.03 & 0.09 & 0.12 \\
\hline 49 & 0.03 & 0.02 & 0.07 & -0.01 & 0.04 & 0.05 \\
\hline Average & 0.08 & 0.05 & 0.12 & -0.02 & 0.04 & 0.07 \\
\hline
\end{tabular}

In the southern part of the Amazon basin the increase in Hydrologic Response can be noted during the 1982/82 El Niño compared to the annual 30-year average. Also noted is the decrease of the response in the northern part of the Amazon Basin, which suggests lower levels of peak and minimum river discharge from the Amazon River itself. According to Zeng (1999), the influence of an ENSO event in Amazon basin runoff occurs up to seven months after the beginning of the event. Therefore, the influence of the on the region can occur within the hydrological year under study and in following years. The soil moistness of the Amazon basin during El Niño events is reduced in the same scale as the precipitation subordinated to an El Niño event (Poveda; Mesa, 1997). Table 3 displays the paired Student's t-test performed to compare the Hydrologic Responses for 1982/83 El Niño and 1974/75 La Niña, for the Amazon region (number ID 10-19). Paired Student's t-test performed to compare those two Hydrologic Responses for the Amazon region showed that they are not significantly different at $1 \%$ (p-value 0.1980). These results agree with Marengo et al. (1998b) showing no significant trends in the discharge or stage records from Amazonia. The differences remarked by those authors for the Amazon basin on the ENSO have behavior which varies with its position: the sub-basin. Central and southern Amazonia present a tendency to have positive Hydrologic Response differences in El Niño periods, while the subbasins of the north have a tendency to present negative differences is Hydrologic Response during El Niño events. Marengo et al. (1998a), assessing the relationship between Amazonia and the El Niño Southern Oscillation state that several authors have found positive (negative) river discharge anomalies in subbasin in the south (north) of Amazonia. They also show similar results for the northern portion of Amazonia where dryer conditions dominate during El Niño events, while more humid conditions prevail in the southern and central regions of Amazonia. As for the 1974/75 La Niña, we also found spatial correlations that are the other way around, as dryer conditions prevail in southern and central Amazônia, while the northern portion accounted for higher Hydrologic Responses. 
Table 3. Comparison of the changes in Hydrologic Response of subbasins located in the Amazon region, for two strong events of El Niño (1982/82) and La Niña (1974/75).

\begin{tabular}{c|c|c|c|c|c|c}
\hline $\begin{array}{c}\text { Basin } \\
\text { ID }\end{array}$ & $\begin{array}{c}\text { 30-year } \\
\text { Average }\end{array}$ & $\begin{array}{c}\boldsymbol{E I} \\
\text { Niño }\end{array}$ & $\begin{array}{c}\mathbf{L a} \\
\text { Niña }\end{array}$ & $\begin{array}{c}\Delta \\
\text { El Niño }\end{array}$ & $\begin{array}{c}\Delta \\
\text { La Niña }\end{array}$ & $\begin{array}{c}\Delta \\
\text { (La Niñ - El Niño) }\end{array}$ \\
\hline 10 & 0.56 & 0.51 & 0.59 & -0.05 & 0.03 & 0.08 \\
11 & 0.58 & 0.64 & 0.56 & 0.06 & -0.02 & -0.08 \\
12 & 0.48 & 0.51 & 0.44 & 0.03 & -0.04 & -0.07 \\
13 & 0.33 & 0.36 & 0.23 & 0.03 & -0.10 & -0.13 \\
14 & 0.39 & 0.37 & 0.31 & -0.02 & -0.08 & -0.06 \\
15 & 0.31 & 0.35 & 0.15 & 0.04 & -0.16 & -0.20 \\
16 & 0.37 & 0.17 & 0.52 & -0.20 & 0.15 & 0.35 \\
17 & 0.32 & 0.37 & 0.25 & 0.05 & -0.07 & -0.12 \\
18 & 0.28 & 0.30 & 0.24 & 0.02 & -0.04 & -0.06 \\
19 & 0.28 & 0.20 & 0.28 & -0.08 & 0.00 & -0.08 \\
\hline Average & $\mathbf{0 . 3 9}$ & $\mathbf{0 . 3 8}$ & $\mathbf{0 . 3 6}$ & $\mathbf{- 0 . 0 2}$ & $\mathbf{- 0 . 0 3}$ & $\mathbf{0 . 0 2}$ \\
\hline
\end{tabular}

The variability of the Hydrologic Response for the southern region and its basins associated with ENSO 1982-83/ La Niña 1974-75 can be depicted in Table 4. Basins 7 and 8 were analyzed together because they belong to the same climatic region in the south of the country. The differences were significant at $1 \%$ (p-value 0.0001). One can see the average difference La Niña - El Niño was -0.18, the negative showing the dryer conditions associated with La Niña and wetter with El Niño. The same tendency was shown for the basins of the Paraná-Paraguai rivers (center-south geographic region), with statistical differences at 1\% (pvalue 0.0015) and average difference La Niña - El Niño of -0.19 (Table 5).

Table 4. Comparison of the changes in Hydrologic Response of subbasins located in the southern region, for two strong events of El Niño (1982/82) and La Niña (1974/75).

\begin{tabular}{c|c|c|c|c|c|c}
\hline $\begin{array}{c}\text { Basin } \\
\text { ID }\end{array}$ & $\begin{array}{c}\text { 30-year } \\
\text { Average }\end{array}$ & $\begin{array}{c}\boldsymbol{E} \boldsymbol{I} \\
\text { Niño }\end{array}$ & $\begin{array}{c}\text { La } \\
\text { Niñ }\end{array}$ & $\begin{array}{c}\Delta \\
\text { EI Niño }\end{array}$ & $\begin{array}{c}\Delta \\
\text { La Niña }\end{array}$ & $\begin{array}{c}\Delta \\
\text { (La Niña - El Niño) }\end{array}$ \\
\hline 70 & 0.44 & 0.60 & 0.31 & 0.16 & -0.13 & -0.29 \\
71 & 0.46 & 0.56 & 0.38 & 0.10 & -0.08 & -0.18 \\
72 & 0.41 & 0.54 & 0.32 & 0.13 & -0.09 & -0.22 \\
73 & 0.48 & 0.75 & 0.43 & 0.27 & -0.05 & -0.32 \\
74 & 0.53 & 0.91 & 0.46 & 0.38 & -0.07 & -0.45 \\
75 & 0.48 & 0.75 & 0.46 & 0.27 & -0.02 & -0.29 \\
76 & 0.37 & 0.43 & 0.39 & 0.06 & 0.02 & -0.04 \\
81 & 0.45 & 0.53 & 0.37 & 0.08 & -0.08 & -0.16 \\
82 & 0.63 & 0.71 & 0.57 & 0.08 & -0.06 & -0.14 \\
83 & 0.57 & 0.53 & 0.61 & -0.04 & 0.04 & 0.08 \\
84 & 0.48 & 0.57 & 0.37 & 0.09 & -0.11 & -0.20 \\
85 & 0.38 & 0.51 & 0.43 & 0.13 & 0.05 & -0.08 \\
86 & 0.42 & 0.55 & 0.35 & 0.13 & -0.07 & -0.20 \\
\hline Average & $\mathbf{0 . 4 4}$ & $\mathbf{0 . 5 7}$ & $\mathbf{0 . 3 9}$ & $\mathbf{0 . 1 3}$ & $\mathbf{- 0 . 0 5}$ & $\mathbf{- 0 . 1 8}$ \\
\hline
\end{tabular}

Ropelewski and Halpert (1987) have studied global and regional precipitation patterns and have noted that the Brazilian northeast is one of the regions of the globe where there is 
the greatest association between ENSO and precipitation. Nine out of eleven drought events studied occurred in association with El Niño years and no wet season occurred during El Niño years. Cavalcanti (1996) found negative precipitation differences in the northeast region and positive ones in the southern region during the decade from 1986 to 1996 in El Niño periods. In the northeast region the worst period occurred during the drought from 1990 to 1993, and only in 1994 did the rainy season present positive rainfall anomalies. On the other hand, in the south of South America the El Niño effect is so strong, however, that there is a clear tendency to increase precipitation. Kousky et al. (1984) described the tendency for severe drought in certain tropical and subtropical regions and excessive precipitation in other regions during the El Niño periods. However, there will not always be a drought, as it depends on other climate forcings.

In Table 6 we display the analysis of the effects of ENSO and La Niña on the hydrologic response for the Tocatins-Araguaia region (center-north). No significance was found at $1 \%$ (p-value 0.0830). Fewer cold fronts reach these areas compared to other basins so no notable effects are expected because of general circulation changes associated with ENSO and La Niña events. In Table 7 there is the same analysis for the Atlantic-East basin (basin ID 50-59). Again no significance is found at $1 \%$ (p-value 0.0326). In these coastal basins, which are in the domain of the Atlantic rainforest atmospheric forcing, has more to do with the South Atlantic anticyclonic circulation pushing moist air over the area.

Table 5. Comparison of the changes is Hydrologic Response of subbasins located in the ParanáParaguai region (center-south geographic region), for two strong events of El Niño (1982/82) and La Niña (1974/75).

\begin{tabular}{c|c|c|c|c|c|c}
\hline $\begin{array}{c}\text { Basin } \\
\text { ID }\end{array}$ & $\begin{array}{c}\text { 30-year } \\
\text { Average }\end{array}$ & $\begin{array}{c}E \boldsymbol{I} \\
\text { Niño }\end{array}$ & $\begin{array}{c}\text { La } \\
\text { Niña }\end{array}$ & $\begin{array}{c}\Delta \\
\text { EI Niño }\end{array}$ & $\begin{array}{c}\Delta \\
\text { La Niña }\end{array}$ & $\begin{array}{c}\Delta \\
\text { (La Niña - El Niño) }\end{array}$ \\
\hline 60 & 0.33 & 0.44 & 0.26 & 0.11 & -0.07 & -0.18 \\
61 & 0.37 & 0.56 & 0.37 & 0.19 & 0.00 & -0.19 \\
62 & 0.26 & 0.41 & 0.18 & 0.15 & -0.08 & -0.23 \\
63 & 0.33 & 0.41 & 0.27 & 0.08 & -0.06 & -0.14 \\
64 & 0.40 & 0.61 & 0.34 & 0.21 & -0.06 & -0.27 \\
65 & 0.52 & 0.66 & 0.49 & 0.14 & -0.03 & -0.17 \\
66 & 0.20 & 0.13 & 0.19 & -0.07 & -0.01 & -0.06 \\
67 & 0.27 & 0.46 & 0.13 & 0.19 & -0.14 & -0.33 \\
\hline Average & $\mathbf{0 . 3 4}$ & $\mathbf{0 . 4 6}$ & $\mathbf{0 . 2 8}$ & $\mathbf{0 . 1 3}$ & $\mathbf{- 0 . 0 6}$ & $\mathbf{- 0 . 1 9}$ \\
\hline
\end{tabular}

Figure 7 shows the river discharge from the Amazon river, measured at the Óbidos fluviometric station (Lat: $1^{\circ} 56^{\prime} 50^{\prime \prime} \mathrm{S}$, Long: $55^{\circ} 30^{\prime} 40^{\prime \prime} \mathrm{W}$ ). The time frame includes the two periods of anomalies cited above (1974-75 for La Niña, 1982-83 for El Niño). The Óbidos station integrates the Hydrologic Responses for the whole Amazon basin above the station. Then the effects of the oscillations are variable, reducing rainfall in the northern part and with such little effect on the southern region that the smaller scale effects are not clearly observable. However, it is seen that in the La Niña period river discharge in Óbidos was near the maximum observed in the period, while for the El Niño period it was near the minimum at the beginning of the period. 
Table 6. Comparison of the changes in Hydrologic Response of subbasins located in the Tocantins-Araguaia region (center-north geographic region), for two strong events of El Niño (1982/82) and La Niña (1974/75).

\begin{tabular}{c|c|c|c|c|c|c}
\hline $\begin{array}{c}\text { Basin } \\
\text { ID }\end{array}$ & $\begin{array}{c}\text { 30-year } \\
\text { Average }\end{array}$ & $\begin{array}{c}\boldsymbol{E} \boldsymbol{N} \\
\text { Niño }\end{array}$ & $\begin{array}{c}\text { La } \\
\text { Niña }\end{array}$ & $\begin{array}{c}\boldsymbol{\Delta} \\
\text { El Niño }\end{array}$ & $\begin{array}{c}\Delta \\
\text { La Niña }\end{array}$ & $\begin{array}{c}\Delta \\
\text { (La Niña - EI Niño) }\end{array}$ \\
\hline 20 & 0.24 & 0.28 & 0.22 & 0.04 & -0.02 & -0.06 \\
21 & 0.24 & 0.28 & 0.16 & 0.04 & -0.08 & -0.12 \\
22 & 0.28 & 0.31 & 0.24 & 0.03 & -0.04 & -0.07 \\
23 & 0.30 & 0.31 & 0.33 & 0.01 & 0.03 & 0.02 \\
24 & 0.38 & 0.44 & 0.24 & 0.06 & -0.14 & -0.20 \\
25 & 0.22 & 0.23 & 0.21 & 0.01 & -0.01 & -0.02 \\
26 & 0.29 & 0.34 & 0.20 & 0.05 & -0.09 & -0.14 \\
27 & 0.28 & 0.25 & 0.33 & -0.03 & 0.05 & 0.08 \\
28 & 0.35 & 0.37 & 0.36 & 0.02 & 0.01 & -0.01 \\
29 & 0.19 & 0.12 & 0.20 & -0.07 & 0.01 & 0.08 \\
\hline Average & $\mathbf{0 . 2 8}$ & $\mathbf{0 . 2 9}$ & $\mathbf{0 . 2 5}$ & $\mathbf{0 . 0 2}$ & $\mathbf{- 0 . 0 3}$ & $\mathbf{- 0 . 0 4}$ \\
\hline
\end{tabular}

Table 7. Comparison of the changes in Hydrologic Response for subbasins located in the East-Atlantic region, for two strong events of El Niño (1982/82) and La Niña (1974/75).

\begin{tabular}{c|c|c|c|c|c|c}
\hline $\begin{array}{c}\text { Basin } \\
\text { ID }\end{array}$ & $\begin{array}{c}\text { 30-year } \\
\text { Average }\end{array}$ & $\begin{array}{c}\boldsymbol{E} \boldsymbol{I} \\
\text { Niño }\end{array}$ & $\begin{array}{c}\text { La } \\
\text { Niña }\end{array}$ & $\begin{array}{c}\Delta \\
\text { EI Niño }\end{array}$ & $\begin{array}{c}\Delta \\
\text { La Niña }\end{array}$ & $\begin{array}{c}\Delta \\
\text { (La Niña - EI Niño) }\end{array}$ \\
\hline 50 & 0.08 & 0.08 & 0.06 & -0.02 & 0.00 & 0.02 \\
51 & 0.08 & 0.08 & 0.06 & -0.02 & 0.00 & 0.02 \\
52 & 0.03 & 0.04 & 0.05 & 0.02 & 0.01 & -0.01 \\
53 & 0.06 & 0.09 & 0.09 & 0.03 & 0.03 & 0.00 \\
54 & 0.21 & 0.20 & 0.38 & 0.17 & -0.01 & -0.18 \\
55 & 0.29 & 0.21 & 0.63 & 0.34 & -0.08 & -0.42 \\
56 & 0.30 & 0.29 & 0.34 & 0.04 & -0.01 & -0.05 \\
57 & 0.34 & 0.32 & 0.35 & 0.01 & -0.02 & -0.03 \\
58 & 0.28 & 0.31 & 0.49 & 0.21 & 0.03 & -0.18 \\
59 & 0.35 & 0.40 & 0.48 & 0.13 & 0.05 & -0.08 \\
\hline Average & $\mathbf{0 . 2 0}$ & $\mathbf{0 . 2 0}$ & $\mathbf{0 . 2 9}$ & $\mathbf{0 . 0 9}$ & $\mathbf{0 . 0 0}$ & $\mathbf{- 0 . 0 9}$ \\
\hline
\end{tabular}

As for other important hydrologic regions, Amarasekera et al. (1997) associated the increase in river discharge in the Paraná River with El Niño years. More recently, Camilloni and Barros (2003) have also proved the correlation that exists between river discharge in the Paraná River and El Niño events. They reported a positive correlation between the ENSO and the positive river discharge anomaly of the high Paraná, placed between the confluence of the Rio Grande and Parnaíba (beginning) and the city of Corrientes in Argentina. They noted that out of the sixteen greatest discharges of the Paraná River in Corrientes, eleven occurred during El Niño, while none occurred in La Niña periods. 


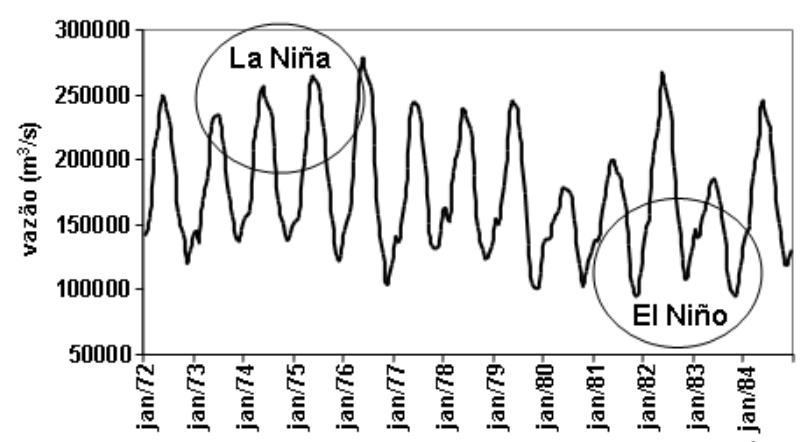

Figure 7. Monthly average river discharge $\left(\mathrm{m}^{3} / \mathrm{s}\right)$ in the Amazon river, measured at the Óbidos Station (Lat: 1 56' 50" S, Long: 55 30' 40" W).

El Niño events result in positive precipitation anomalies in the south, while La Niña years produce negative anomalies. Ropelewski and Halpert (1987) have stressed that in the south of the country, out of sixteen El Niño events studied there were fourteen episodes of higher rainfall.

Based on the period chosen to represent the normal climatic forcing and the two extreme events of El Niño and La Niña, the overall analysis showed no significant differences for El Niño - La Niña years for the Amazon region and the Araguaia-Tocantins basins (North and center-north of the country). For the other regions we found differences. The southern half of the country (including south, southeast Paraná-Paraguai), the El Niño anomaly of more precipitation was also seen in the water production from the basins, with La Niña responding with a negative anomaly in water availability. The northeast semi-arid region where droughts are severe were affected the other way around, with El Niño reducing the already low water production and La Niña being a positive anomaly for water flowing out of the basins.

\section{CLOSING REMARKS}

Hydrological response maps were obtained for all the large hydrological regions in Brazil, considering 74 subbasins, for 30 hydrological years from 1970 to 2000. These maps show that the Hydrological Response follows the country's climatological pattern, considering precipitation, radiation and phytogeographic distribution as climate modulators and indicators. We found very high responses for the west of Amazonia and the south of Brazil (reaching 0.7), average to high values for central Amazonia the mid-west and the southeast of the country (0.3-0.5 range) and very low responses for all the Drought Area (close to 0.1).

Interannual hydrometeorological variability, in particular the precipitation anomalies associated with the El Niño and La Niña, produce changes in the annual Hydrologic Responses for some hydrological regions of the country. El Niño events aggravate the dryness of the Brazilian northeast and reduce Hydrologic Responses in the northern part of the Amazon region. The other way around, El Niño increases the Hydrological Response with more rainfall in the basins in the south of the country. La Niña events produce an increase in Hydrologic Response in the northeast and a reduction in the subbasins in the southern region.

By normalizing fluvial water flow by rainfall, Hydrologic Response brings direct and comparable information for managing hydrological basins. 


\section{REFERENCES}

ALMEIDA, A. C.; SOARES, J. V. Comparação entre uso de água em plantações de Eucalyptus grandis e Floresta Ombrófila Densa (mata Atlântica) na costa leste do Brasil. Revista Árvore, Viçosa, v. 27, n. 2, p. 159-170, 2003.

AMARASEKERA, K. N.; LEE, R. F.; WILLIAMS, E. R.; ELTAHIR, E. A. B. ENSO and natural variability in the flow of tropical rivers. Journal of Hydrology, Amsterdam, v. 200, n. 1/4, p. 24-39, 1997.

BRASIL. Ministério da agropecuária, pecuária e abastecimento. Instituto Nacional de Meteorologia. Laboratório de Energia Solar. Atlas de irradiação solar do Brasil. Porto Alegre: UFSC, 1998.

Ministério de Minas e Energia. Departamento Nacional de Águas e Energia Elétrica. Divisão de Controle de Recursos hídricos. Inventário das Estações Fluviométricas. Brasília, Ministério de Minas e Energia, 1997.

Ministério do Meio Ambiente. Agência Nacional de Águas. 2003. Available at: $<$ http://www.ana.gov.br>. Accessed on 1 June 2003.

CAMILLONI, I. A.; BARROS, V. R. Extreme discharge events in The Paraná River and their climate forcing. Journal of Hydrology, Amsterdam, v. 278, n. 1/4, p. 94-106, 2003.

CARRIELLO, F. Estimativas da resposta hidrológica das sub-bacias brasileiras. 2004. 155f. Dissertation (Mestrado em Sensoriamento Remoto) - Instituto Nacional de Pesquisas Espaciais, São José dos Campos, 2004.

CAVALCANTI, I. F. A. Episódios de El Niño/Southern Oscillation durante a década de 1986 a 1996 e suas influências sobre o Brasil. Climanálise, São José dos Campos, ed. comemorativa, 1996. Available at: <http://www.cptec.inpe.br/products/climanalise/ cliesp10a/nino.html>. Accessed on 11 sept. 2003.

HEWLETT, J. D. Principles of Forest Hydrology. Athens: The University of Georgia Press, 1982. $183 \mathrm{p}$.

HEWLETT, J. D.; HIBBERT, A. R. Factors affecting the response of small watersheds to precipitation in humid areas. In: SOPPER, W. E.; LULL, H. W. (Eds.). International Symposium on Forest Hydrology. Oxford: Pergamon Press, 1967. p. 275-290.

KOUSKY, V. E.; KAGANO, M. T.; CAVALCANTI, I. F. A. A review of the southern oscillation: oceanic-atmospheric circulation changes and related rainfall anomalies. Tellus A, Stockholm, n. 36, a. 5, p. 490-504, 1984.

MARENGO, J. A.; NOBRE, C. A.; SAMPAIO, G. On the associations between hydrometeorological conditions in Amazonia and the extremes of the Southern Oscillation. Bulletin de l'Institut Français des Etudes Andines, Lima, v. 27, n. 3, p. 789-802, 1998a.

MARENGO, J. A.; TOMASELLA, J.; UVO, C. R. Trends in streamflow and rainfall in tropical South America: Amazonia, eastern Brazil, and northwestern Peru. Journal of Geophysical Research-Atmospheres, St. Louis, v. 103, n.D2, p. 1775-1783, 1998 b. 
MARENGO, J. A.; UVO, C. B. Variabilidade e Mudança Climática in Brasil e América do Sul. Climanálise, São José dos Campos, ed. comemorativa, 1996. Available at: $<$ www.cptec.inpe.br/products/climanalise/cliesp10a/mudanca.html $>$. Accessed on 22 june 2003.

NEW, M.; HULME, M.; JONES, P. Representing etwentieth-century space-time climate variability. Part I: development of a 1961-90 mean monthly terrestrial climatology. Journal of Climate, Boston, v. 12, n. 3, p. 829-856, 1999.

Part II: development of 1901-96 monthly grids of terrestrial surface climate. Journal of Climate, Boston, v. 13, n. 13, p. 2217-2238, 2000.

NEW, M.; LISTER, D.; HULME, M.; MAKIN, I. A high-resolution data set of surface climate over global land areas. Climate Research, Oldendorf, v. 21, n. 1, p. 1-25, 2002.

POVEDA, G.; MESA, O. J. Feedbacks between hydrological processes in tropical South America and large-scale ocean-atmospheric phenomena. Journal of Climate, Boston, v. 10, n. 10, p. 2690-2702, 1997.

ROBERTS, J. M.; CABRAL, O. M. R.; COSTA, J. P.; MC WILLIAM, A. L. C.; SÁ, T. D. $A$. An overview of the leaf area index and physiological measurements during ABRACOS. In: GASH, J. H. C.; NOBRE, C. A.; ROBERTS, J. M.; VICTORIA, R. L. (Eds.). Amazonian deforestation and climate. Chichester: John Wiley, 1996. p. 287306.

ROPELEWSKI, C. F.; HALPERT, M. S. Global and regional scale precipitation patterns associated with the El Niño/southern oscillation. Monthly Weather Review, Boston, v.115, p. 1606-1626, 1987.

SOARES, J. V.; ALMEIDA, A. C. 2001. Modeling the water balance and soil water fluxes in a fast growing Eucalyptus plantation in Brazil. Journal of Hydrology, Amsterdam, v. 253, n. 1, p. 131-148, 2001.

TRENBERTH, K. E. The definition of El Niño. Bulletin of the American Meteorological Society, Boston, n. 78, p. 2771-2777, 1997.

WOODRUF, J. F.; HEWLETT, J. D. Predicting and mapping the average hydrologic response in the eastern United States. Water Resource Research, [S.l.], v. 6, n. 5, p. 1312-1326, 1970.

ZENG, N. 1999. Seasonal cycle and interannual variability in the Amazon hydrologic cycle. Journal of Geophysical Research, St. Louis, n. 104, v. D8, p. 9097-9106, 1999. 